\title{
Health Risk Assessment of Heavy Metals in Traditional Cosmetics Sold in Tunisian Local Markets
}

\author{
Mohamed Anouar Nouioui, ${ }^{1,2}$ Salah Mahjoubi, ${ }^{1,2}$ Asma Ghorbel, ${ }^{1,2}$ \\ Marouen Ben Haj Yahia, ${ }^{3}$ Dorra Amira, ${ }^{1,2}$ Hayet Ghorbel, ${ }^{1,2}$ and Abderrazek Hedhili ${ }^{1,2}$ \\ ${ }^{1}$ Centre d'Assistance Médicale et Urgente CAMU, 1008 Tunis Cedex, Tunisia \\ ${ }^{2}$ Laboratoire de Toxicologie et Environnement LR12SP07, 10 rue Abou Kacem Chabbi, Montfleury, 1008 Tunis Cedex, Tunisia \\ ${ }^{3}$ Laboratoires de Pharmaceutiques, Cosmétiques et Détergents, Centre Technique de la Chimie, 12 rue de l'Usine, \\ Charguia II, Carthage, 2035 Tunis, Tunisia
}

Correspondence should be addressed to Mohamed Anouar Nouioui; anouar_nouioui@yahoo.fr

Received 27 September 2015; Revised 16 December 2015; Accepted 30 December 2015

Academic Editor: Christophe Waterlot

Copyright (C) 2016 Mohamed Anouar Nouioui et al. This is an open access article distributed under the Creative Commons Attribution License, which permits unrestricted use, distribution, and reproduction in any medium, provided the original work is properly cited.

\begin{abstract}
This study was undertaken in order to determine heavy metal contents in twelve $(n=12)$ henna brands and eleven $(n=11)$ kohl products. An analytical test was performed for $\mathrm{Pb}, \mathrm{Cd}, \mathrm{Cu}$, and $\mathrm{Zn}$ in henna and kohl products using atomic absorption spectrophotometery. The overall mean concentrations of heavy metals in henna varied between 1.2 and $8.9 \mu \mathrm{gg}^{-1}$ for $\mathrm{Pb} ; 0.8$ and $18.6 \mu \mathrm{gg}^{-1}$ for $\mathrm{Cd}$; $0.5 \mu \mathrm{gg}^{-1}$ and $3.3 \mu \mathrm{gg}^{-1}$ for $\mathrm{Cu}$; and $3.7 \mu \mathrm{gg}^{-1}$ and $90.0 \mu \mathrm{gg}^{-1}$ for $\mathrm{Zn}$. As for kohl products, Pb concentrations ranged between $51.1 \mu \mathrm{gg}^{-1}$ and $4839.5 \mu \mathrm{gg}^{-1}$, Cd concentrations ranged between $1.0 \mu \mathrm{gg}^{-1}$ and $158.6 \mu \mathrm{gg}^{-1}$, Cu concentrations ranged between $2.5 \mu \mathrm{gg}^{-1}$ and $162.5 \mu \mathrm{g} \mathrm{g}^{-1}$, and $\mathrm{Zn}$ concentrations ranged between $0.7 \mu \mathrm{g} \mathrm{g}^{-1}$ and $185.0 \mu \mathrm{gg}^{-1}$. The results of our study revealed that $\mathrm{Pb}, \mathrm{Cd}, \mathrm{Cu}$, and $\mathrm{Zn}$ contents in investigated samples were high, making from the prolonged use of such products a potential threat to human health. Therefore, major quality controls are recommended in order to enforce acceptable limits of potential contaminants in cosmetics and good manufacturing practice.
\end{abstract}

\section{Introduction}

Personal care products and facial cosmetics are commonly used by millions of consumers on a daily basis. Direct application of cosmetics on human skin makes it vulnerable to a wide variety of ingredients. Despite the protecting role of skin against exogenous contaminants, some of the ingredients in cosmetic products are able to penetrate the skin and to produce systemic exposure [1-4].

Natural and synthetic substances may produce local effects on human skin, such as irritation, sensitization, allergy, or photoreactions $[3,5]$. Among the hazardous substances contained in cosmetics, heavy metals are widely diffused in colored make-up products.

Henna and kohl are typical examples of traditional cosmetics widely used in Middle East and North Africa. Henna "Lawsonia inermis" is a flowering plant and the sole species of the Lawsonia genus. Its powder has been used since antiquity to dye skin, hair, and fingernails, as well as fabrics including silk, wool, and leather. Kohl is a powder traditionally made by grinding galena and other ingredients to darken the eyelids or as a mascara for the eyelashes [6].

These two products may contain relatively large amounts of heavy metals present in ingredients or accidently introduced during the preparation steps.

In fact, kohl or surma as eye cosmetic has been identified as a suspected source of $\mathrm{Pb}$ exposure to the ocular system in a number of adults and children [7-9]. It is composed mainly of galena $(\mathrm{PbS})$, amorphous carbon, zincite $(\mathrm{ZnO})$, sassolite $\left(\mathrm{H}_{3} \mathrm{BO}_{3}\right)$, minium $\left(\mathrm{Pb}_{3} \mathrm{O}_{4}\right)$, magnetite $\left(\mathrm{Fe}_{3} \mathrm{O}_{4}\right)$, goethite $(\mathrm{FeO}(\mathrm{OH}))$, cuprite $\left(\mathrm{Cu}_{2} \mathrm{O}\right)$, and talc $\left(\mathrm{Mg}_{3} \mathrm{Si}_{4} \mathrm{O}_{10}(\mathrm{OH})_{2}\right)[10-$ 14]. Because of its composition, kohl is considered by the US Food and Drug Administration (FDA) as unsafe for use and as an illegal substance to be imported or sold in the United States $[15,16]$ while, in other countries such as Tunisia, it is still largely sold in markets without any legal control. 
Henna cultivated in contaminated zones may also be considered as a potential source of poisoning by heavy metals and its daily use may increase the body intake on heavy metals through percutaneous absorption. Besides, the excipients used with henna to fix the color may contain $\mathrm{p}$ phenylenediamine (PPD), a toxic organic substance derivative of aniline which is responsible for many serious health problems.

For an accurate determination of heavy metal contents in cosmetic products, a variety of analytical techniques have been used for the assessment of metals in cosmetics, such as Laser Induced Breakdown Spectroscopy (LIBS) [17], Inductively Coupled Plasma Mass Spectrometry (ICP-MS) [18], Inductively Coupled Plasma-Optical Emission Spectrometry (ICP-OES) [19], Flame Atomic Absorption Spectrometry (FAAS) [4, 20], and Graphite Furnace Atomic Absorption Spectrometry (GFAAS) [21].

The high risk of heavy metal contamination by traditional locally sourced cosmetics sold in Tunisian markets in the absence of any legal control such as henna and kohl requires a thorough examination of their contents of trace metals.

Therefore, the objective of the present study was to examine the content of henna and kohl samples commonly sold in Tunisian markets.

\section{Materials and Methods}

2.1. Study Design. The study was carried out by the laboratory of toxicology and environment. Samples were collected from a well-known local open market in Tunis, Tunisia, where it is possible to buy inexpensive cosmetic products. At these shops, personal care products imported from different countries as well as those locally manufactured are sold. The target samples were only kohl and henna products because they are widely used among the Tunisian population and did not include high quality brand cosmetic products that are generally sold in beauty stores or pharmacies. The sampling was designed to ensure a maximum number of different brands of henna and kohl products. Every kohl and henna brand sold in the market was analyzed at least in triplicate. Keeping in view their daily use and their possible health impacts, twelve henna brands and eleven kohl products were purchased to assess their contents of heavy metals. Among the selected henna brands, six brands were imported from Sudan, India, Lybia, and Pakistan and the rest were locally manufactured. Concerning kohl samples, nine brands were imported from India, Pakistan, China, Saudi Arabia, and France and five were local brands. Samples were stored at room temperature until analysis.

2.2. Reagents and Standards. Analytical grade nitric acid $65 \%(\mathrm{w} / \mathrm{v})$, perchloric acid $70 \%(\mathrm{w} / \mathrm{v})$, and sulfuric acid 96\% (w/v) purchased from Merck (Darmstadt, Germany) were used for sample preparation. Aqueous calibration solutions of $\mathrm{Pb}, \mathrm{Cd}, \mathrm{Zn}$, and $\mathrm{Cu}$ were prepared by appropriate dilutions of certified stock solutions (1000 $\left.\mathrm{mg} \mathrm{L}^{-1}\right)$ purchased from Wako (Wako, Japan). Plastic bottles, polyethylene tubes, autosampler cups, and glassware were soaked in $10 \%(\mathrm{v} / \mathrm{v})$
$\mathrm{HNO}_{3}$ for $24 \mathrm{~h}$, rinsed with Milli-Q water, dried, and stored in a closed polypropylene container.

2.3. Sample Digestion. Henna samples were wetly digested following the recommendations of the International Atomic Energy Agency (IAEA) [22] and according to the procedure reported by Lekouch et al. [23] with slight modifications. Henna samples were oven-dried overnight at $70^{\circ} \mathrm{C}$ to constant weight and then stored in desiccators. $0.2 \mathrm{~g}$ of each of the dried samples was accurately weighed in Teflon tubes. $5 \mathrm{~mL}$ of nitric acid was added and the samples were kept for $1 \mathrm{~h}$ at room temperature and then placed in aluminium block on hot plate at $90^{\circ} \mathrm{C}$ and digested for $3 \mathrm{~h}$. The digests were cooled and filtered with Whatman number 42 and were diluted up to the mark $(50 \mathrm{~mL})$ into a calibrated flask.

Kohl samples were wetly digested with 2:1:1 mixture of nitric acid (65\%), sulfuric acid (96\%), and perchloric acid (70\%) [23] on a hot plate in fuming hood near to dryness [24] by increasing the temperature for $2-3 \mathrm{~h}$. The solutions were left to be cooled and filtered into a calibrated flask $(50 \mathrm{~mL})$ by Whatman number 42 and were diluted up to the mark.

2.4. Sample Analysis. Precise determination of heavy metals content in cosmetic products is quite important because there is a narrow margin of safety between adequate amount and overconsumption. Among the various methods suggested for heavy metals analysis in cosmetic products, atomic absorption spectrometry was the most frequently used because of its relative simplicity, lower cost, and low sample volume requirements and its low detection limits.

Due to the unavailability of certified reference material for metal analysis in kohl and henna, the accuracy of the method was determined by measuring the recovery of analytes. Spiked henna and kohl samples were run with the test samples and blanks using the same procedure. The analytical recovery for $\mathrm{Pb}, \mathrm{Cd}, \mathrm{Zn}$, and $\mathrm{Cu}$ at concentrations tested $(0.02$ and $0.1 \mu \mathrm{g} \mathrm{mL}^{-1}$ ) ranged between 95 and $105 \%$.

2.4.1. Graphite Furnace Atomic Absorption Spectrophotometry GFAAS. $\mathrm{Pb}$ and $\mathrm{Cd}$ concentrations were detected by Shimadzu AA 6800 atomic absorption spectrophotometer (Shimadzu, Kyoto, Japan) equipped with GFA-EX7 graphite furnace atomizer and ASC 6100 Autosampler (Shimadzu, Kyoto, Japan). Atomization was made on pyrolytic coated graphite tubes from Shimadzu. Nonspecific absorption of radiation was corrected using deuterium background correction. Integrated absorbance (peak area) was used for signal evaluation.

$\mathrm{Pb}$ and $\mathrm{Cd}$ hollow cathode lamps from Hamamatsu Photonics (Kyoto, Japan), operating at 10 and $8 \mathrm{~mA}$, respectively, were used as radiation sources. The absorbance was read at 283.3 and $228.8 \mathrm{~nm}$, respectively. Argon (99.999\%) (Air Liquid, Tunis, Tunisia) was used as the purge gas. The furnace heating program is shown in Table 1 . The absorbance was measured three times. Calibration standards were prepared using standard addition method. Each digested samples were divided into six equal portions to whom known amount of aqueous $\mathrm{Pb}$ and $\mathrm{Cd}$ concentrations were added to give final concentrations which covered the range 0 to $0.1 \mu \mathrm{g} \mathrm{mL}^{-1}$ and 
TABLE 1: Temperature heating program for graphite furnace atomic absorption spectrophotometer.

\begin{tabular}{lcccccc}
\hline \multirow{2}{*}{ Step } & \multicolumn{2}{c}{ Temp. $\left({ }^{\circ} \mathrm{C}\right)$} & \multicolumn{2}{c}{ Time $(\mathrm{s})$} & Heat mode & \multirow{2}{*}{ Ar flow rate $\mathrm{mL} \cdot \mathrm{min}^{-1}$} \\
\hline 1 & $\mathrm{~Pb}$ & $\mathrm{Cd}$ & $\mathrm{Pb}$ & $\mathrm{Cd}$ & Ramp & 250 \\
2 & 170 & 170 & $10(10)$ & $10(10)$ & Ramp & 250 \\
3 & 250 & 250 & $15(10)$ & $15(10)$ & Ramp & 250 \\
4 & $600(800)$ & $350(550)$ & $3(2)$ & $6(3)$ & Step & 0 \\
5 & $600(800)$ & $350(550)$ & $4(3)$ & $4(3)$ & Step & 0 \\
6 & $1500(1500)$ & $1700(1700)$ & 3 & 3 & Step & 250 \\
\hline
\end{tabular}

Tpyr $(\mathrm{Pb}): 600^{\circ} \mathrm{C}$ for henna and $800^{\circ} \mathrm{C}$ for kohl; Tatom $(\mathrm{Pb}): 1500^{\circ} \mathrm{C}$ for henna and kohl; Tpyr $(\mathrm{Cd}): 350^{\circ} \mathrm{C}$ for henna and $550^{\circ} \mathrm{C}$ for kohl; Tatom $(\mathrm{Cd}): 1700^{\circ} \mathrm{C}$ for henna and kohl.

0 to $0.008 \mu \mathrm{g} \mathrm{mL}^{-1}$ for Cd. Dilution correction was applied for samples diluted or concentrated during analysis.

2.4.2. Flame Atomic Absorption Spectrophotometry. Analyses of kohl sample were carried out on a flame spectrophotometer (Perkin Elmer $308 \mathrm{~B}$ ) for $\mathrm{Cu}$ and $\mathrm{Zn}$. The absorbance was read at $324.7 \mathrm{~nm}$ and $213.9 \mathrm{~nm}$ at $0.7 \mathrm{~nm}$ slit width. The calibration curves were linear up to $5 \mu \mathrm{g} \mathrm{mL} L^{-1}$ for $\mathrm{Cu}$ and $1 \mu \mathrm{g} \mathrm{mL}^{-1}$ for $\mathrm{Zn}$. The gas flow used for the flame analysis was as follows: air, $13.5 \mathrm{~L} \mathrm{~min}^{-1}$; and acetylene, $2 \mathrm{~L} \mathrm{~min}^{-1}$.

2.4.3. Energy Dispersive X-Ray Fluorescence Spectrometry EDXRF. For EDXRF analysis, samples were necessarily ground to a powder and then mounted in sample cups. Diffraction data were collected using Bruker S2 Ranger spectrometer with XFlash $^{\circledast}$ Silicon Drift Detector and $50 \mathrm{KV}$ Pd X-Ray Tube. These data were used to determine the elemental composition present in samples. The detection was qualitative and the elemental range covered all elements from $\mathrm{Na}$ to U. A bright metallic kohl in rock form identified as galena or lead sulfide was also analyzed for comparison with local kohl product.

\section{Results and Discussions}

In this study, twelve henna brands and eleven kohl (surma) products purchased from local Tunisian markets were analyzed for assessment of $\mathrm{Pb}, \mathrm{Cd}, \mathrm{Cu}$, and $\mathrm{Zn}$ contents. Results were summarized in Table 2 .

3.1. Heavy Metal Contents in Kohl Samples. The overall $(n=$ 11) mean concentrations of analyzed heavy metals were as follows: $1926.9 \pm 70.4 \mu \mathrm{gg}^{-1}$ (range: $54.1-4839.5 \mu \mathrm{gg}^{-1}$ ) with the highest concentration in surma "S-10" and the lowest in surma "S-9" for $\mathrm{Pb} ; 59.5 \pm 1.9 \mu \mathrm{g} \mathrm{g}^{-1}$ (range: $0.0-$ $158.6 \mu \mathrm{g} \mathrm{g}^{-1}$ ) with the highest concentration in surma " $\mathrm{S}-10$ " and minimum (not detectable) in surma "S-9" for Cd; $80.4 \pm$ $0.5 \mu \mathrm{g} \mathrm{g}^{-1}$ (range: $0.7-185 \mu \mathrm{g} \mathrm{g}^{-1}$ ) with the highest concentration observed in surma "S-10" followed by the lowest concentration in surma "S-9" for $\mathrm{Zn}$; and $43.9 \pm 0.3 \mu \mathrm{gg}^{-1}$ (range: $2.5-162.5 \mu \mathrm{g} \mathrm{g}^{-1}$ ) with the highest concentration in surma " $\mathrm{S}$ 3 " and the lowest concentration in surma "S-4" for Cu.

In order to establish the predominant contaminant in the analyzed kohl samples, the mean heavy metal contents were arranged in decreasing order. The result was the following: $\mathrm{Pb}>\mathrm{Zn}>\mathrm{Cd}>\mathrm{Cu}$. Thus, in analyzed samples, $\mathrm{Pb}$ was the most predominant element. Its concentration was much higher than all the other investigated metals. This finding was also reported by Ullah et al. [25] for different brands of kohl purchased from a local market in Pakistan. All the analyzed kohl products contained more $\mathrm{Cu}$ than $\mathrm{Cd}$ while, in the present study, the content of $\mathrm{Cu}$ was slightly lower than $\mathrm{Cd}$.

Purchased samples were also divided into two groups. The first group entailed all the products which were manufactured in Tunisia while the second group included all imported items. Many of the local marketed kohl products were "homemade" products. These products were prepared according to local traditions by herbalists or unauthorized companies and sold in markets unlabeled and without proper packing. The traditional recipes of kohl may include the incorporation of various herbs like pepper, musk, and ginger.

All foreign kohl brands were imported from eastern countries including India, Pakistan, China, and Saudi Arabia with the exception of kohl S-9 which was manufactured in France.

Both groups contained considerable amounts of heavy metals and showed a wide variation among the samples. The overall mean concentrations of $\mathrm{Pb}$ in local kohl samples were $2020 \pm 90.9 \mu \mathrm{gg}^{-1}$ versus $1849.3 \pm 53.2 \mu \mathrm{gg}^{-1}$ in imported products.

The overall mean concentrations of $\mathrm{Cd}$ in local kohl products were $71.1 \pm 2.9 \mu \mathrm{gg}^{-1}$ versus $47.9 \pm 2.4 \mu \mathrm{gg}^{-1}$ in foreign brands. For $\mathrm{Zn}$ and $\mathrm{Cu}$ contents in local brands, the overall mean concentrations were $76.6 \pm 0.4 \mu \mathrm{gg}^{-1}$ and $87.0 \pm 0.5 \mu \mathrm{gg}^{-1}$ versus $83.6 \pm 0.6 \mu \mathrm{gg}^{-1}$ and $8.0 \pm 0.2 \mu \mathrm{g} \mathrm{g}^{-1}$, respectively, in imported brands. With the exception of $\mathrm{Zn}$ content, all the local brands revealed higher concentrations of $\mathrm{Pb}, \mathrm{Cd}$, and $\mathrm{Cu}$.

These findings were predictable since as previously mentioned, many of the local products were home-made prepared without precautions against contamination by heavy metals. These "home-made" kohl samples are often prepared by grinding galena (lead sulfide) instead of amorphous carbon or organic charcoal. Plant oils and the soot from various nuts, seeds, and gum resins are often added. Unfortunately, the nonlead products are considered to be of inferior quality to the older traditional varieties and, therefore, there has been an increase in the use of handmade, lead-based kohl. 
TABLE 2: Descriptive statistical summary of heavy metal concentration (mean \pm SD) in kohl and henna in $\mu \mathrm{gg}^{-1}$.

\begin{tabular}{|c|c|c|c|c|c|c|}
\hline Product type & Origin & Color & $\mathrm{Pb}$ & $\mathrm{Cd}$ & $\mathrm{Zn}$ & $\mathrm{Cu}$ \\
\hline \multicolumn{7}{|l|}{ Kohl (surma) } \\
\hline & Local & & & & & \\
\hline S1 & Tunisia & Black & $1954.9 \pm 7.62$ & $152.1 \pm 4.1$ & $21.0 \pm 0.1$ & $82.5 \pm 0.1$ \\
\hline S2 & Tunisia & Black & $3759.0 \pm 9.83$ & $81.9 \pm 5.3$ & $14.5 \pm 0.1$ & $52.5 \pm 0.2$ \\
\hline S3 & Tunisia & Black & $1504.9 \pm 7.62$ & $7.5 \pm 0.5$ & $107.5 \pm 0.5$ & $162.5 \pm 2.1$ \\
\hline S4 & Tunisia & Black & $135.9 \pm 1.36$ & $4.4 \pm 0.3$ & $102.5 \pm 0.2$ & $2.5 \pm 0.1$ \\
\hline S5 & Tunisia & Black & $2745.5 \pm 19.06$ & $109.7 \pm 4.4$ & $137.5 \pm 1.0$ & $135 \pm 0.1$ \\
\hline \multirow[t]{2}{*}{ Mean \pm SD $(n=3)$} & & & $2020.0 \pm 9.09$ & $71.1 \pm 2.9$ & $76.6 \pm 0.4$ & $87.0 \pm 0.5$ \\
\hline & Foreign & & & & & \\
\hline S6 & India & Dark black & $2483.6 \pm 9.85$ & $4.2 \pm 0.6$ & $25.0 \pm 0.3$ & $3.2 \pm 0.1$ \\
\hline S7 & Pakistan & Dark black & $101 \pm 1.36$ & $1.0 \pm 0.5$ & $112.5 \pm 0.5$ & $7.0 \pm 0.1$ \\
\hline S8 & China & Dark Black & $240.8 \pm 1.48$ & $3.9 \pm 0.7$ & $3.5 \pm 0.1$ & $6.3 \pm 0.1$ \\
\hline S9 & France & Dark black & $51.1 \pm 2.1$ & ND & $0.7 \pm 0.1$ & $6.7 \pm 0.3$ \\
\hline S10 & India & Dark black & $4839.5 \pm 4.07$ & $158.6 \pm 7.7$ & $185.0 \pm 1.5$ & $15.0 \pm 0.2$ \\
\hline S11 & Saudi Arabia & Dark black & $3379.9 \pm 14.98$ & $71.8 \pm 2.4$ & $175.0 \pm 1.2$ & $10.0 \pm 0.1$ \\
\hline Mean $\pm \operatorname{SD}(n=3)$ & & & $1849.3 \pm 5.32$ & $47.9 \pm 2.4$ & $83.6 \pm 0.6$ & $8.0 \pm 0.2$ \\
\hline Overall mean $\pm \mathrm{SD}(n=11)$ & & & $1926.9 \pm 7.04$ & $59.5 \pm 1.9$ & $80.4 \pm 0.5$ & $43.9 \pm 0.3$ \\
\hline Overall min & & & 51.1 & 1.0 & 0.7 & 2.5 \\
\hline Overall max & & & 4839.5 & 158.6 & 185.0 & 162.5 \\
\hline \multicolumn{7}{|l|}{ Henna } \\
\hline & Local & & & & & \\
\hline $\mathrm{H} 1$ & Tunisia & Green & $6.7 \pm 0.8$ & $5.1 \pm 1.1$ & $55.0 \pm 0.2$ & ND \\
\hline $\mathrm{H} 2$ & Tunisia & Red/light brown & $5.5 \pm 0.7$ & $12.9 \pm 0.6$ & $47.0 \pm 0.2$ & $0.5 \pm 0.1$ \\
\hline $\mathrm{H} 3$ & Tunisia & Green & $1.2 \pm 0.3$ & $5.9 \pm 0.2$ & $4.2 \pm 0.1$ & ND \\
\hline $\mathrm{H} 4$ & Tunisia & Green & $2.7 \pm 0.0$ & $1.8 \pm 0.1$ & $10.0 \pm 0.2$ & $0.5 \pm 0.0$ \\
\hline H5 & Tunisia & Green & $3.5 \pm 0.6$ & $1.1 \pm 0.2$ & $7.5 \pm 0.1$ & $3.3 \pm 0.1$ \\
\hline H6 & Tunisia & Green & $3.2 \pm 0.1$ & $4.8 \pm 0.2$ & $12.5 \pm 0.1$ & $3.3 \pm 0.1$ \\
\hline \multirow[t]{2}{*}{ Mean $\pm \operatorname{SD}(n=3)$} & & & $3.8 \pm 0.4$ & $5.3 \pm 0.4$ & $22.7 \pm 0.2$ & $1.9 \pm 0.1$ \\
\hline & Foreign & & & & & \\
\hline $\mathrm{H} 7$ & Sudan & Green & $8.9 \pm 0.5$ & $4.3 \pm 0.9$ & $21.0 \pm 0.1$ & $0.7 \pm 0.1$ \\
\hline $\mathrm{H} 8$ & India & Green & $6.0 \pm 0.4$ & $14.9 \pm 0.6$ & $15.0 \pm 0.1$ & $1.2 \pm 0.1$ \\
\hline H9 & Yemen & Green & $5.4 \pm 0.1$ & $18.6 \pm 0.7$ & $47.5 \pm 0.2$ & ND \\
\hline $\mathrm{H} 10$ & Libya & Green & $2.6 \pm 0.9$ & $18.1 \pm 0.8$ & $90.0 \pm 0.2$ & ND \\
\hline H11 & Libya & Green & $4.8 \pm 0.2$ & $6.9 \pm 0.7$ & $3.7 \pm 0.1$ & $0.7 \pm 0.0$ \\
\hline $\mathrm{H} 12$ & Pakistan & Green & $1.8 \pm 0.2$ & $0.8 \pm 0.2$ & $6.2 \pm 0.2$ & $1.0 \pm 0.1$ \\
\hline Mean \pm SD $(n=3)$ & & & $4.9 \pm 0.4$ & $10.6 \pm 0.6$ & $30.6 \pm 0.2$ & $0.9 \pm 0.1$ \\
\hline Overall mean \pm SD $(n=12)$ & & & $4.3 \pm 0.4$ & $7.9 \pm 0.5$ & $26.6 \pm 0.2$ & $1.4 \pm 0.1$ \\
\hline Overall min & & & 1.2 & 0.8 & 3.7 & 0.5 \\
\hline Overall max & & & 8.9 & 18.6 & 90.0 & 3.3 \\
\hline
\end{tabular}

The lowest concentrations of $\mathrm{Pb}$ and $\mathrm{Cd}$ were in sample S-9 manufactured in France while the highest concentrations were in sample S-10 manufactured from India. Although the number of brands was small for any statistical comparison, the difference in terms of $\mathrm{Pb}, \mathrm{Cd}$, and $\mathrm{Zn}$ contents between the product imported from France and all other products including the locally manufactured ones was remarkable. This difference questions the way of preparing the kohl products and the nature of ingredients used. Unfortunately, due to the small number of samples in the present case, this matter could not be investigated. However, this problem has been raised by a Danish survey conducted on different brands of commercialized kohl in Denmark. In all the samples investigated, the highest concentration was measured in product from India [26]. According to the authors of the survey, the difference was attributed to the way of manufacturing kohl between "eastern" and "western" countries and the lack of good manufacturing practice [26]. The elemental composition of one lead-based local kohl sample (S-5) was investigated by energy dispersive X-ray fluorescence (EDXRF) and compared to that of unprocessed natural stone "hajar" kohl product sold in the market. 
TABLE 3: \% of weight elemental composition of local kohl sample (S-5) and natural stone "hajar" kohl sample using EDXRF.

\begin{tabular}{lccc}
\hline \multicolumn{2}{c}{ Lead-based local sample (S-5) } & \multicolumn{2}{c}{ A natural stone kohl sample } \\
Formula & Weight \% & Formula & Weight \% \\
\hline $\mathrm{Pb}$ & 94.09 & $\mathrm{~Pb}$ & 96.59 \\
$\mathrm{Ca}$ & 1.03 & $\mathrm{Ca}$ & 1.19 \\
$\mathrm{Si}$ & 0.98 & $\mathrm{Cl}$ & 0.67 \\
$\mathrm{Cu}$ & 0.38 & $\mathrm{P}$ & 0.63 \\
$\mathrm{Cl}$ & 0.29 & $\mathrm{~S}$ & 0.18 \\
$\mathrm{P}$ & 0.27 & $\mathrm{Cd}$ & 0.06 \\
$\mathrm{As}, \mathrm{Fe}$ & 0.26 & $\mathrm{Fe}$ & 0.03 \\
$\mathrm{Zn}$ & 0.23 & $\mathrm{Ti}$ & 0.20 \\
$\mathrm{Al}$ & 0.14 & $\mathrm{Zn}$ & 0.02 \\
$\mathrm{Cd}$ & 0.08 & $\mathrm{Sn}, \mathrm{Sb}$ & 0.01 \\
$\mathrm{Sb}$ & 0.05 & $\mathrm{Cu}, \mathrm{Ni}, \mathrm{Co}, \mathrm{Cr}$ & $<0.01$ \\
$\mathrm{Ni}, \mathrm{Co}, \mathrm{Cr}$ & $<0.01$ & & \\
\hline
\end{tabular}

The EDXRF analysis of the natural stone kohl sample revealed $\mathrm{Pb}$ levels in excess of $96.59 \%$ of product weight (Table 3). The lustre and high $\mathrm{Pb}$ content as well as the presence of sulfur are consistent with its traditional identity as galena or Pb sulfide (Figure 1(a)). As for the local home-made kohl sample (S-5), the comparison to the spectra of the kohl stone revealed that this home-made kohl powder consisted predominantly of $\mathrm{Pb}$ (94.09\%) explaining its high $\mathrm{Pb}$ concentration $\left(2745 \mu \mathrm{g} \mathrm{g}^{-1}\right)$. Zinc and copper were also identified at levels of $0.23 \%$ and $0.38 \%$ of the product weight, respectively. Other elements including sulfur, calcium, chlorine, and silicon were also present at low concentrations (Table 3).

Comparison between literature and current study showed that the obtained $\mathrm{Pb}$ concentrations were close to those found in kohl samples from Middle East and Asia. Ullah et al. [25] conducted a study to determine heavy metal contents by FAAS in 15 cosmetic products both imported and locally manufactured by unauthorized company marketed at district Kohat, in Pakistan. The investigated products included three nonmedicated shampoos, three talc powders, three lipsticks, three kohl samples, and three cream samples. The highest contents for $\mathrm{Pb}$ were found in two kohl samples with overall mean concentrations of $1071 \mu \mathrm{g} \mathrm{g}^{-1}$ and $1005 \mu \mathrm{gg}^{-1}$. Al-Ashban et al. [27] analyzed $\mathrm{Pb}$ along with $\mathrm{Al}$ and $\mathrm{Sb}$ in a total of $107 \mathrm{kohl}$ samples (branded and unbranded) collected from different regions of Saudi Arabia by atomic absorption spectrometry. The analyzed kohl samples originated from commercial manufacturers from Saudi Arabia, Pakistan, India, and Iran. The authors stated that about $35 \%$ of kohl products sold were prepared by kohl sellers themselves and most of this kohl was sold without proper labels and packing while $65 \%$ of kohl sellers obtained properly labelled kohl from different sources. $\mathrm{Pb}$ levels up to $53 \%(\mathrm{w} / \mathrm{w})$ of the product $\left(530000 \mu \mathrm{gg}^{-1}\right)$ were detected in some kohl preparations. Maximum $\mathrm{Al}$ and $\mathrm{Sb}$ concentrations were found to be 0.557 and $0.21 \%$, respectively. Some samples were found to contain camphor and menthol. The blood of 20 regular kohl users was also analyzed and results showed high
$\mathrm{Pb}$ concentration and relatively low haemoglobin levels. High $\mathrm{Pb}$ contents were also reported by Lekouch et al. [23] in 10 kohl samples obtained from local herbalists in the Marrakech markets. Four kohl samples were originated from Yemen, Algeria, Sudan, and Saudi Arabia and the rest were local products. $\mathrm{Pb}$ concentrations were extremely high in all types of analyzed kohl. Local kohl was particularly charged with $\mathrm{Pb}(89 \% \mathrm{w} / \mathrm{w})$ especially the kohl composed of pure galena. Lower concentrations were found in some types of "spiced" kohl where kohl is mixed with various herbs and animal and mineral products. The authors explained this difference by the fact that the addition of many excipients dilutes the concentration of $\mathrm{Pb}$ in kohl. The elemental composition of $21 \mathrm{kohl}$ specimens consisting of 6 home-made powders, 9 commercial preparations, and 6 natural stone kohl samples originating from various parts of Saudi Arabia, India, and the Middle East was investigated by Al-Hazzaa and Krahn [28] using energy dispersive X-ray analysis (EDXRF). The data revealed the presence of significant $\mathrm{Pb}$ levels in two-thirds of the kohl specimens analyzed at concentrations ranging from 2.9 to $100 \% \mathrm{w} / \mathrm{w}$ (mean $48.5 \%$ ). Other elements were present in kohl preparations including $\mathrm{Al}, \mathrm{C}, \mathrm{Fe}, \mathrm{Ti}, \mathrm{Ca}, \mathrm{Mg}, \mathrm{O}, \mathrm{Ag}$, $\mathrm{Si}, \mathrm{S}$, and $\mathrm{Sb}$. Only $7 \mathrm{kohl}$ specimens were totally lead-free, 4 had $\mathrm{Pb}$ contents in the range of $2.9 \%-34.1 \% \mathrm{w} / \mathrm{w}$, and 10 had lead levels in excess of $84 \%$. Carbon levels in excess of $60 \%$ were detected in six kohl samples and Sb was present in only one kohl specimen at a concentration of 7.8\%. Hardy et al. [10] reported that, among $18 \mathrm{kohl}$ samples purchased from Cairo and analyzed using X-ray powder diffraction (XRPD) and scanning electron microscopy (SEM), the main component of six samples (4 originated from Egypt and 2 from India) was found to be galena (PbS). For a further ten samples the main component was found to be one of the following: amorphous carbon, calcite $\left(\mathrm{CaCO}_{3}\right)$, cuprite $\left(\mathrm{Cu}_{2} \mathrm{O}\right)$, goethite $(\mathrm{FeO}(\mathrm{OH}))$, and elemental silicon or talc $\left(\mathrm{Mg}_{3} \mathrm{Si}_{4} \mathrm{O}_{10}(\mathrm{OH})_{2}\right)$. As For the last two samples, the main component of each was an unknown amorphous organic compound. Besides, in a previous work conducted on $23 \mathrm{kohl}$ samples obtained in the United Arab Emirates (19 from Abu Dhabi and 4 from Dubai) using X-ray powder diffraction (XRPD) and scanning electron microscopy (SEM), Hardy et al. [12] reported that the main component found in 11 samples was galena ( $\mathrm{PbS}$ ) while, for the remaining 12 samples, the main component was found to be one of the following: amorphous carbon, zincite $(\mathrm{ZnO})$, sassolite $\left(\mathrm{H}_{3} \mathrm{BO}_{3}\right)$, or calcite/aragonite $\left(\mathrm{CaCO}_{3}\right)$. $\mathrm{Pb}$ was also detected in 26 brands of lipsticks and 8 different brands of eye shadows marketed in Saudi Arabia. The mean lead concentrations in lipsticks samples were in the range of $0.27-3760 \mu \mathrm{gg}^{-1}$ wet weight. Four brands of lipsticks had $\mathrm{Pb}$ concentration above $20 \mu \mathrm{g} \mathrm{g}^{-1}$ and three brands from China with mean concentrations of $2720.5 \mu \mathrm{g} \mathrm{g}^{-1}, 2522.5 \mu \mathrm{g} \mathrm{g}^{-1}$ and $3760 \mu \mathrm{gg}^{-1}$ wet weight. As for $\mathrm{Pb}$ content in pressed powder eye shadow, the mean concentrations ranged from 0.42 to $58.7 \mu \mathrm{g} \mathrm{g}^{-1}$ wet weight with only one brand with $\mathrm{Pb}$ content exceeding $20 \mu \mathrm{g} \mathrm{g}^{-1}$ [21]. Lower $\mathrm{Pb}$ contents have also been reported in the literature. In A Danish survey conducted on 18 samples of kohl and 17 samples of henna purchased from retail shops and ethnic shops and analyzed by ICP-MS, $\mathrm{Pb}$ was found in 10 products 


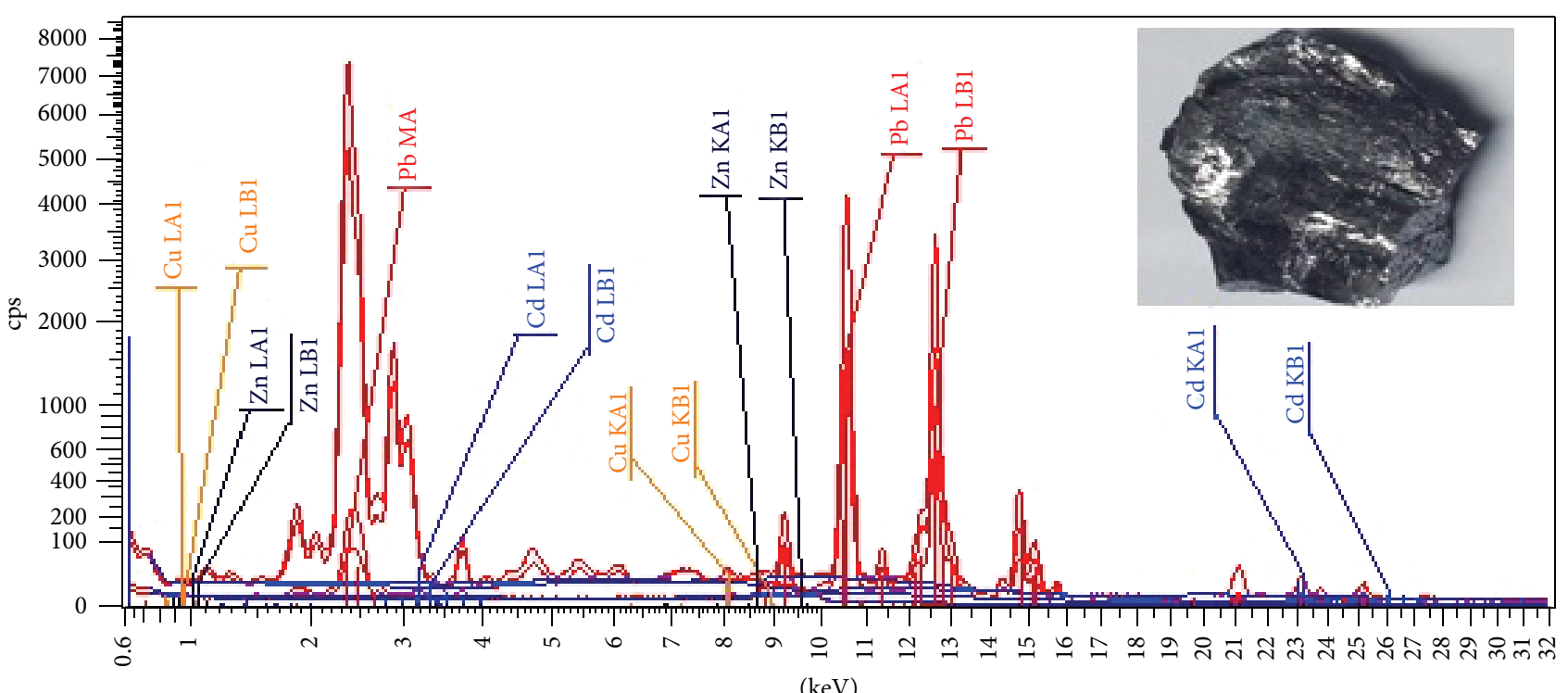

(a)

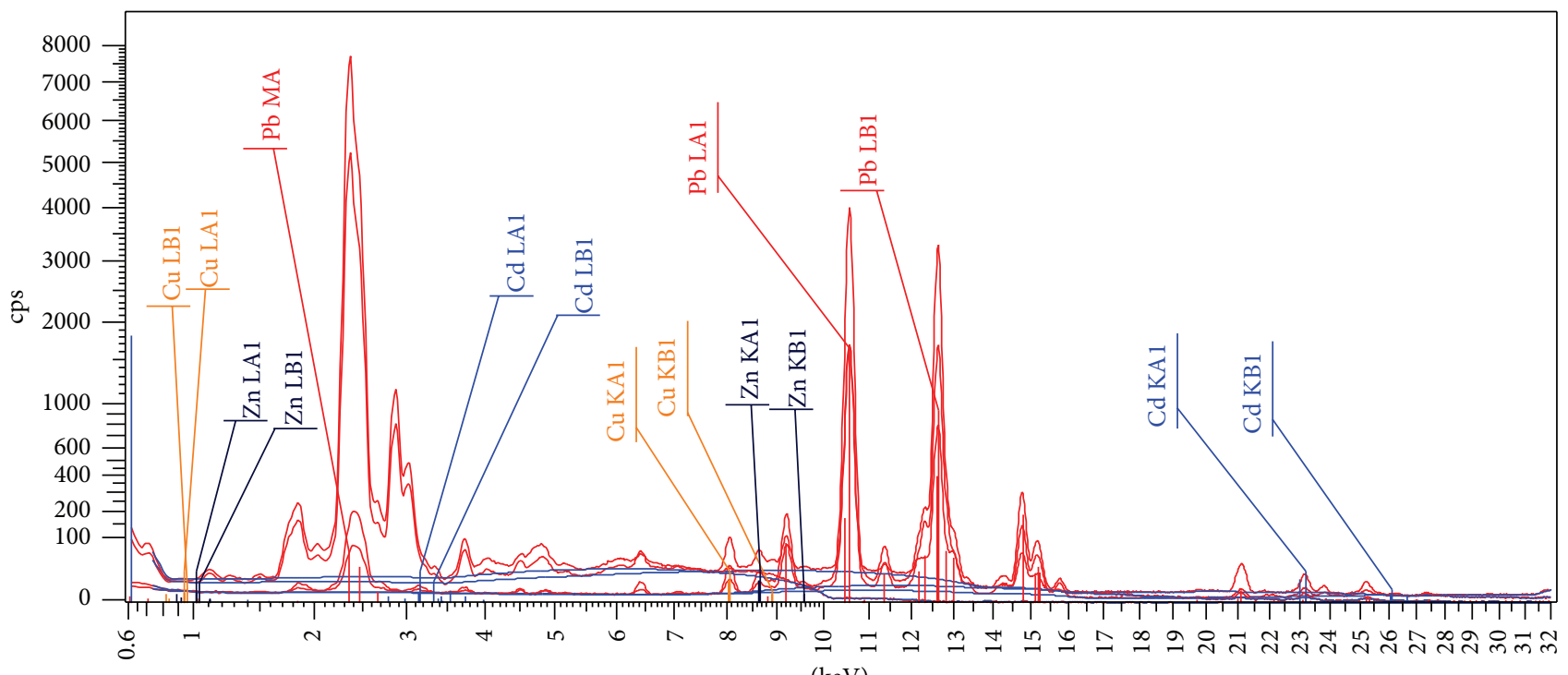

$(\mathrm{keV})$

(b)

FIGURE 1: EDXRF spectra of both (a) the natural stone kohl sample and (b) the local kohl sample (S-5).

at a mean concentration ranging from 0.30 to $1 \mu \mathrm{g} \mathrm{g}^{-1}$, and in 4 products at a concentration ranging from 1 to $4 \mu \mathrm{g} \mathrm{g}^{-1}$. $\mathrm{Pb}$ was only found at high concentration $\left(280 \mu \mathrm{g} \mathrm{g}^{-1}\right)$ in one kohl product that was manufactured in India [26].

Volpe et al. [4] evaluated the content of $\mathrm{Pb}$ in 20 samples of eye shadows marketed in a local open market and in a franchise store in Benevento, Italy. The content of $\mathrm{Pb}$ was measured by FAAS while the quantification of $\mathrm{Cd}, \mathrm{Co}, \mathrm{Cr}$, and Ni was performed by ICP-MS. Mean $\mathrm{Pb}$ concentrations ranged between $0.25 \mu \mathrm{gg}^{-1}$ and $81.50 \mu \mathrm{gg}^{-1}$. The highest values corresponded to eye shadows imported from China.

As for Cd content in kohl, the results of our study were higher than those reported by Volpe et al. [4] for Cd content in eye shadow where $\mathrm{Cd}$ mean levels ranged from $0.6 \mathrm{ng} \mathrm{g}^{-1}$ to $33.4 \mathrm{ng} \mathrm{g}^{-1}$. The mean Cd levels reported by Ullah et al. [25] in kohl samples varied from 0.095 to $0.942 \mu \mathrm{g} \mathrm{g}^{-1}$ and only three products among the $18 \mathrm{kohl}$ samples analyzed by the Danish survey contained $\mathrm{Cd}$ at concentrations of $0.06 \mu \mathrm{gg}^{-1}, 0.08 \mu \mathrm{gg}^{-1}$, and $1.8 \mu \mathrm{gg}^{-1}$ [26]. For Cu content in kohl, the highest amount found was $162.5 \mu \mathrm{gg}^{-1}$ in a local brand (S-3) with an overall mean concentration of $43.9 \mu \mathrm{g} \mathrm{g}^{-1}$ for all the analyzed $11 \mathrm{kohl}$ samples. This value was approximately two times lower than the overall mean concentration reported by Ullah et al. [25] for the 3 tested kohl samples (104.57 $\mathrm{Mg} \mathrm{g}^{-1}$ ) in which the highest $\mathrm{Cu}$ amount was found in kohl manufactured in Pakistan $\left(302.2 \mu \mathrm{g} \mathrm{g}^{-1}\right)$. 
Copper was also found at a concentration of $950 \mu \mathrm{gg}^{-1}$ in a kohl sample manufactured from India [26].

The highest $\mathrm{Zn}$ content in the 11 kohl samples analyzed was $185 \mu \mathrm{gg}^{-1}$ in kohl from India with an overall mean content of $80.4 \mu \mathrm{gg}^{-1}$. This result was two times lower than the overall mean $\mathrm{Zn}$ content found $\left(254.55 \mu \mathrm{g} \mathrm{g}^{-1}\right)$ by Ullah et al. [25] for the three kohl products from Pakistan. The reported values were $1.362 \mu \mathrm{g} \mathrm{g}^{-1}, 253.5 \mu \mathrm{g} \mathrm{g}^{-1}$, and $508.8 \mu \mathrm{g} \mathrm{g}^{-1}$. Higher amount of $\mathrm{Zn}$ was also reported. $\mathrm{Zn}$ was found in one kohl sample at high concentration $\left(115000 \mu \mathrm{g} \mathrm{g}^{-1}\right)$ corresponding to $11.5 \%(\mathrm{w} / \mathrm{w})$ of the product [26]. The kohl sample was the same product which contained $950 \mu \mathrm{g} \mathrm{g}^{-1}$ of $\mathrm{Cu}$ [26]. Al-Dayel et al. [29] analyzed 9 brands of the most expensive brands names of mascara and eyeshade from the Saudi market. Twenty-eight elements were determined by ICP-MS and flow injection mercury system (FIMS). The highest $\mathrm{Zn}$ concentration was $2000 \mu \mathrm{g} \mathrm{g}^{-1}$ in one of the eyeshades. In several facial cosmetics, $\mathrm{Zn}$ concentrations of $94.4,111.9$, and $94.9 \mu \mathrm{g} \mathrm{g}^{-1}$ have been reported in eye liners, eye pencils, and lipsticks purchased from open market in Nigeria [30].

Due to the high levels of heavy metals found in kohl products which are widely used as traditional cosmetic in the Tunisian population, strict legislation must be established to ban the use of $\mathrm{Pb}$ and $\mathrm{Cd}$ as ingredients in the kohl formula. As for consumers, it is recommended not to purchase unlabeled products and to be selective while purchasing cosmetics.

3.2. Heavy Metal Contents in Henna Samples. Based on the overall mean concentrations, the mean heavy metal contents in henna products were in the following decreasing order: $\mathrm{Zn}$ $>\mathrm{Cd}>\mathrm{Pb}>\mathrm{Cu}$.

$\mathrm{Pb}$ levels in henna ranged from 1.2 to $6.7 \mu \mathrm{gg}^{-1}$ with an overall mean concentration of $4.3 \pm 0.4 \mu \mathrm{g} \mathrm{g}^{-1}$. Pb mean concentrations found in both locally manufactured and imported brands were similar. In comparison to the literature, our results were close to the results found by Bernth et al. [26] about 17 henna products purchased from retail and ethnic shops in Denmark and analyzed by ICP-MS. Pb was found along other heavy metals in 10 out of the 17 analyzed products. The concentrations of lead in 10 of the analyzed products ranged from $0.5 \mu \mathrm{gg}^{-1}$ to $2.0 \mu \mathrm{g} \mathrm{g}^{-1}$. Paraphenylene diamine (PPD) was found in 3 of the 17 products. The lowest PPD concentration was $0.003 \%$ (w/w), while the highest content was $17 \%(\mathrm{w} / \mathrm{w})$ corresponding to $170 \mathrm{~g} \mathrm{~kg}^{-1}$. $\mathrm{Al}-$ Saleh and Coate [31] analyzed $\mathrm{Pb}$ in 20 henna products obtained from the local herbalist in the Riadh market in Saudi Arabia by GFAAS. Pb mean concentrations ranged from 1.29 to $16.48 \mu \mathrm{g} \mathrm{g}^{-1}$ with the highest $\mathrm{Pb}$ concentration found in a black henna sample imported from Sudan. Pb was also determined by Jallad and Espada-Jallad [32] in 12 commercial and traditional henna samples obtained from local consumer products' superstores in Sharjah and Dubai in the United Arab Emirates. The concentrations found in henna ranged from $2.29 \mu \mathrm{g} \mathrm{g}^{-1}$ to $65.98 \mu \mathrm{g} \mathrm{g}^{-1}$. The highest lead concentration was found in a local black henna paste. Lekouch et al. [23] found that the average concentrations of $\mathrm{Pb}$ in 20 henna samples obtained from local herbalists in the Marrakech market ranged from 2.2 to $6.5 \mu \mathrm{g} \mathrm{g}^{-1}$. The two highest $\mathrm{Pb}$ levels were recorded in two local black henna samples at concentration of 15.5 and $19.9 \mu \mathrm{g} \mathrm{g}^{-1}$.

As for $\mathrm{Cd}$, the levels ranged from 1.1 to $12.9 \mu \mathrm{g} \mathrm{g}^{-1}$ in the local brands (group 1) and from 0.8 to $18.6 \mu \mathrm{g} \mathrm{g}^{-1}$ in imported products (group 2) with the highest Cd level found in henna products from Yemen and Lybia (H-9 and $\mathrm{H}-10)$.

The obtained results were higher than those reported by Bernth et al. [26] where Cd was detected in only four henna samples at concentrations ranging from 0.05 to $0.07 \mu \mathrm{g} \mathrm{g}^{-1}$.

In the present study, $\mathrm{Zn}$ levels ranged from 3.7 to $90 \mu \mathrm{g} \mathrm{g}^{-1}$ with the highest $\mathrm{Zn}$ concentration found in henna product from Lybia (H-10).

Alwakeel [33] analyzed 5 kinds of henna available in herb markets around the city of Riadh in Saudi Arabia along with 27 samples of well-known herbs. The average mean concentrations ranged from 0.307 to $0.607 \mu \mathrm{gg}^{-1}$ for $\mathrm{Zn}$ and from 0.088 to $0.178 \mu \mathrm{g} \mathrm{g}^{-1}$ for $\mathrm{Cu}$.

The screening for heavy metals in 17 samples of henna conducted by Bernth et al. [26] detected $\mathrm{Zn}$ at concentrations ranging from 0.55 to $76 \mu \mathrm{g} \mathrm{g}^{-1}$.

As for $\mathrm{Cu}$ levels in henna samples, results ranged between 0.5 and $3.3 \mu \mathrm{gg}^{-1}$ in local brands and between 0.7 and $1.2 \mu \mathrm{g} \mathrm{g}^{-1}$ in imported products (group 2). These results were close to those found by Bernth et al. [26] where $\mathrm{Cu}$ mean concentrations ranged between 0.14 and $12 \mu \mathrm{gg}^{-1}$.

One possible explanation of the data disparity in literature regarding heavy metals contents between henna brands is the difference in the way of manufacturing the product (different chemical coloring additives) and the product origin. In fact, henna thrives outside arid regions. The countries of origin of this powder are several in number with very different climates. Thereby, the chemical constitution could be variable [34].

In Tunisia, henna plants are cultivated in the region of Gabes located in the southeastern part of Tunisia. This region is well-known for phosphoric acid industries that generate tons of phosphogypsum. This by-product rich with $\mathrm{Cd}$ has contaminated the soil and the groundwater of the region for decades. So, Cd among other metals can accumulate in plant tissues at concentrations above the threshold levels believed to threaten the health of human beings.

Henna like kohl is widely used as a traditional cosmetic for hair care and hair dyeing as an alternative to permanent chemical hair dyeing. Henna leaves are picked, dried, grinded to powder, then mixed, and stirred to paste before being massaged into the dry hair and the skull of the head or used as a tattoo on the skin. The red brownish color of henna is derived from a natural substance called lawsone. Other color nuances could be obtained by mixing henna powder with other ingredients such as citrus, pomegranate peel, and gall of Tamarix orientalis. Some other chemicals could be added to alter the color of henna including synthetic dye, solvents, and metal salts. Metal salts can interact with the other chemicals, oil, and wax and cause health problems. The most frequently used metal salt in henna was $\mathrm{Pb}$ acetate [35]. Some henna pastes have been also noted to include 


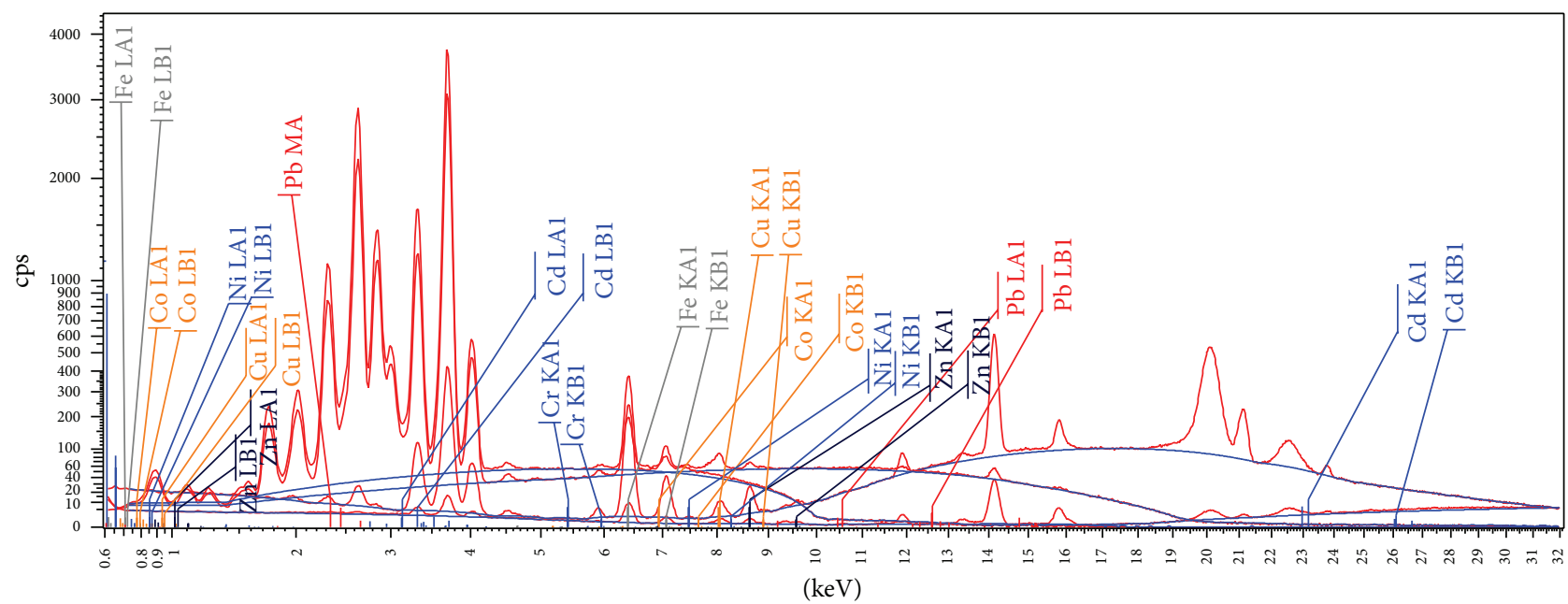

(a)

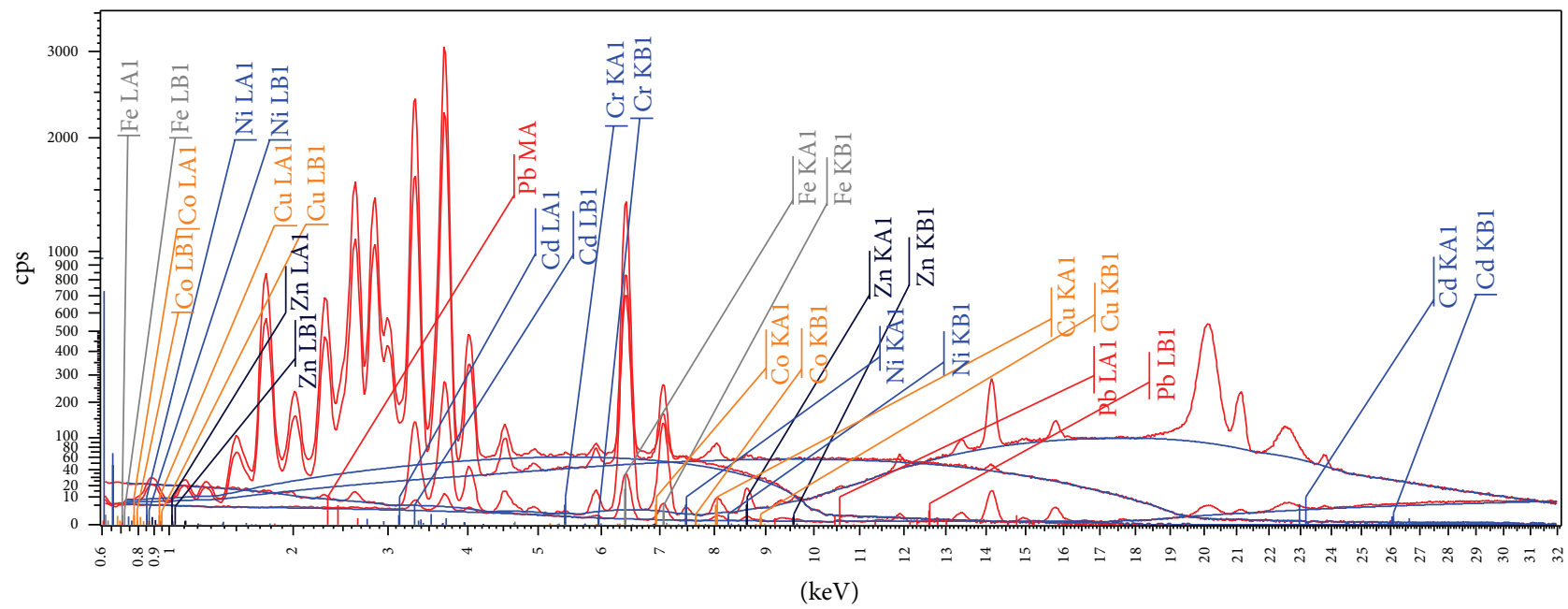

(b)

FIGURE 2: EDXRF spectra of both the (a) green henna sample (H-1) and of the (b) red-brown henna (H-2) sample.

silver nitrate, carmine, pyrogallol, disperse orange dye, and chromium [36]. Black henna has been reported to contain considerable amounts of PPD used to enhance its dark color [36]. In North Africa, especially in the Maghreb region, there are many varieties of henna depending on the traditional way of preparing this cosmetic product. The major difference is in the substances added to henna. Various mineral products rich in trace metals can be mixed with henna such as mercury (zawaq), copper oxide (hadida), zinc oxide (Tûtiya), and litharge $\mathrm{PbO}$ (limrataq) [23]. In the present study, all the analyzed henna samples were of green powder except for one local brand sample $\mathrm{H}-2$ where henna color was light red brownish.

Although the quantitative analysis of $\mathrm{Pb}, \mathrm{Cd}, \mathrm{Zn}$, and $\mathrm{Cu}$ in this sample " $\mathrm{H} 2$ " showed concentrations at the same levels as the other types of henna, the association between its color and its trace metal contents has been further investigated. Since the EDXRF can give a clear indication of the elemental composition, it was used to test the presence of any significant metals that could explain the red brownish color of the henna sample "H-2." The EDXRF detected $\mathrm{Pb}, \mathrm{Cd}, \mathrm{Zn}$, and $\mathrm{Cu}$ at trace levels $(<0.1 \%$ weight of the sample) in both green henna sample ( $\mathrm{H}-1)$ and red-brown henna sample ( $\mathrm{H}-2)$. Calcium $(\mathrm{CaO})$ and silicon $\left(\mathrm{SiO}_{2}\right)$ were also identified as major components in the EDXRF spectra of both green henna (H1) and red-brown henna (sample $\mathrm{H}-2$ ). The presence of $\mathrm{SiO}_{2}$ in henna has been also reported by Jallad and EspadaJallad [32] in both red and black paste henna products from the Emirates. $\mathrm{SiO}_{2}$ (silica) was reported to be a main constituent of the horsetail extract powder derived from the plant Equisetum hyemale and which was mixed with henna powder and used to stimulate, heal, and soften both hair and skin.

As for the presence of other metal salts in henna, iron, manganese, nickel, and cobalt have been identified at low levels $(<0.05 \%)$. The comparison between both EDXRF spectra for green (Figure 2(a)) and red-brown henna (Figure 2(b)) showed similar patterns and their elemental composition in terms of heavy metals was similar (Table 4) though Fe levels 
TABLE 4: \% of weight composition of local red henna sample (H-2) and green henna sample (H-1) using EDXRF.

\begin{tabular}{lccc}
\hline \multicolumn{2}{c}{ Local red Henna sample (H-2) } & \multicolumn{2}{c}{ Local green } \\
Formula & Weight $\%$ & Formula & Weight $\%$ \\
\hline $\mathrm{Na}$ & 37.50 & $\mathrm{Ca}$ & 33.19 \\
$\mathrm{Ca}$ & 17.09 & $\mathrm{Na}$ & 22.30 \\
$\mathrm{~K}$ & 12.59 & $\mathrm{~K}$ & 13.77 \\
$\mathrm{Si}$ & 11.61 & $\mathrm{Cl}$ & 6.47 \\
$\mathrm{Fe}$ & 6.66 & $\mathrm{~S}$ & 6.07 \\
$\mathrm{Al}$ & 4.54 & $\mathrm{Mg}$ & 5.80 \\
$\mathrm{~S}$ & 3.59 & $\mathrm{Si}$ & 4.26 \\
$\mathrm{Cl}$ & 2.41 & $\mathrm{P}$ & 2.46 \\
$\mathrm{P}$ & 1.58 & $\mathrm{Fe}$ & 2.38 \\
$\mathrm{Mn}$ & 0.44 & $\mathrm{Al}$ & 1.42 \\
$\mathrm{Zn}$ & 0.08 & $\mathrm{Mn}$ & 0.11 \\
$\mathrm{As}, \mathrm{Cd}$ & 0.04 & $\mathrm{Zn}$ & 0.07 \\
$\mathrm{~Pb}, \mathrm{Cu}, \mathrm{Cr}, \mathrm{Ni}, \mathrm{Co}$ & $<0.01$ & $\mathrm{Cu}, \mathrm{Sb}, \mathrm{Sn}$ & 0.04 \\
& & $\mathrm{Cd}$ & 0.03 \\
& & $\mathrm{~Pb}$ & 0.02 \\
& & $\mathrm{As}, \mathrm{Ni}, \mathrm{Co}, \mathrm{Cr}$ & $<0.01$ \\
\hline
\end{tabular}

were higher in red henna (6.66\%) than in green one $(2.38 \%)$. However, the difference between the two products was not significant for any certain attribution of the red-brown colors to the presence of metal salts. Further investigations should be carried out to unveil the origin of this red color.

3.3. Toxicity of Heavy Metal. We can note that, in most of the analyzed products, $\mathrm{Pb}$ and $\mathrm{Cd}$ contents exceed the limits of 20 and $10 \mu \mathrm{g} \mathrm{g}^{-1}$ set by the US Food and Drug Administration (FDA) as maximum amounts of $\mathrm{Pb}$ and $\mathrm{Cd}$ allowed in color additives used to make cosmetic for external use produced in good manufacturing practices. Taking into consideration its toxicology, kohl is not allowed in USA nor is it allowed to be used in cosmetics $[15,16]$. Unfortunately, there are no current international standards for impurities in cosmetics. The Canadian regularity limits for certain metals in cosmetics are $10 \mu \mathrm{gg}^{-1}$ for $\mathrm{Pb}, 3 \mu \mathrm{gg}^{-1}$ for $\mathrm{As}$, $\mathrm{Cd}$, and $\mathrm{Hg}$, and $5 \mu \mathrm{g} \mathrm{g}^{-1}$ for $\mathrm{Sb}$ [37]. Other legislations like the Danish Statutory Order on Cosmetics number 489 [38] have banned the marketing of all cosmetic products containing $\mathrm{Pb}, \mathrm{Cd}, \mathrm{Sb}, \mathrm{As}, \mathrm{Ba}, \mathrm{Cd}, \mathrm{Cr}$, $\mathrm{Tl}, \mathrm{Ni}, \mathrm{Co}$, and potassium bromine. Rather than taking a riskbased approach, the German limits are based on levels that could be technically avoided. Thus, heavy metal impurities are limited to anything above normal background levels. Accordingly, $\mathrm{Pb}$ and $\mathrm{Cd}$ content in cosmetic products at concentrations above $20 \mu \mathrm{g} \mathrm{g}^{-1}$ and $5 \mu \mathrm{g} \mathrm{g}^{-1}$, respectively, are considered technically avoidable [39].

As for $\mathrm{Zn}$ levels in cosmetics, the FDA has classified zinc oxide as category I ingredient for use in cosmetic products as UV filter in concentrations of up to $25 \%(w / w)$ [40] while the Scientific Committee on Cosmetics and Non-Food Products (SCCNFP) intended for consumers required more information to enable a proper safety evaluation of micronised zinc oxide for use as UV filter in cosmetic products including possible pathways of cutaneous penetration and systemic exposure [41]. As for the Japanese Ministry of Health and Welfare limits of $1 \%$ and $0.5 \%$ of the product weight have been adopted as maximum amounts of zinc and copper substituted zeolite in cosmetic not used for mucosa [42].

A daily application of cosmetic products with considerable amounts of $\mathrm{Pb}, \mathrm{Cd}, \mathrm{Zn}$, and $\mathrm{Cu}$ on the skin such as the present products marketed in Tunisia can potentially add up to significant exposure levels. The skin absorption of heavy metals salts varies greatly with different physical parameters. In fact, heavy metals bind with the proteins of the cell by forming complexes with carboxylic acid $(-\mathrm{COOH})$, amine $\left(-\mathrm{NH}_{2}\right)$, and thiol $(-\mathrm{SH})$, hindering their functions and causing death of the cells which lead to multiple diseases [43]. The elevated levels of $\mathrm{Pb}$ found in the commercialized kohl samples present a potential risk especially for pregnant women who are more vulnerable consumers as it can easily pass through the placenta. Increased levels of lead in the blood of infants to whom kohl was applied have been well documented [9, 44-47].

In fact, several studies have associated the use of kohl with the elevated blood lead levels in children. A US study showed a significant difference between blood lead levels of children of Pakistani and Indian communities exposed to kohl and those of the same communities not exposed to this product $\left(0.62 \mu \mathrm{mol} \mathrm{L}^{-1}\right.$ versus $\left.0.21 \mu \mathrm{mol} \mathrm{L}^{-1}\right)$ [8]. The poisoning of children by $\mathrm{Pb}$ from kohl products could be through oral ingestion as young children tend to rub their eyes when they are irritated by kohl and to put their contaminated fingers in their mouths [12]. Absorption through the nasolacrimal duct or tear duct has also been proposed [8].

The intestinal absorption of $\mathrm{Pb}$ is influenced by the type of the ingested derivatives and the gastrointestinal contents and by age. In addition, it is increased in the presence of certain nutritional deficiencies particularly by those of iron, as well as calcium [48].

Also, in adult users of kohl, increased lead blood levels have been observed following its use [27, 49]. Studies of the health effects conducted on kohl showed that adults absorb $5-15 \%$ and children can absorb about $41 \%$ of the ingested lead [29]. Children under two years of age are particularly vulnerable because the fractions of ingested lead which is absorbed slowly decrease until the age of 2 years and more rapidly, thereafter, approach the adult level absorption around the age of 10 years [48].

Henna has long been used in the countries of the Middle East and North Africa for its cosmetic or therapeutic properties. It has been used for the treatment of certain skin lesions and infected burns. Several of its therapeutic properties have been recently proven. Its anti-inflammatory, antipyretic, analgesic, and even tuberculostatic properties were experimentally demonstrated [50-52]. Despite its low allergic potential, some allergic reactions have been reported. Most of them were delayed-type hypersensitivity reactions and allergic contact dermatitis [23, 53-55].

A toxicological characterization of lawsone, a main bioactive ingredient of henna, was conducted by the European Scientific Committee on Cosmetic Products and Non-Food 
Products (SCCNFP) intended for consumers in 2004. This latter proposed to consider lawsone as class $2 \mathrm{~A}$ of dangerous substances due to its potential genotoxicity/mutagenicity [34].

Furthermore, henna is known to be dangerous to people with glucose-6-phosphate dehydrogenase deficiency (G6PD deficiency) which is more common in males than in females [56]. A case of acute poisoning was also reported for a girl aged 15 following a suicidal ingestion of an unknown amount of henna. The autopsy reported laryngeal edema, pulmonary congestion, and pathological disorders related to anaphylaxis [57]. Another case of acute poisoning by henna was also reported for a woman aged 45 following a voluntary ingestion of a liter of henna-based solution prescribed by traditional medicine as a treatment for colitis. Severe bloody diarrhea with abdominal pain and fever was reported [58]. Henna in itself remains a rare and weak skin sensitizer and in most cases allergic reactions were not caused by henna but by the chemical substances added to henna, mainly pphenylenediamine $[54,55]$.

In Maghreb countries, this substance is sold by arborist as a rock named "Takouat Roumia." Being sold over the counter, this highly toxic product has become the preferred substance for suicide attempts. Numerous cases of poisoning and death by this substance have been reported [59].

Metal salts among other ingredients in marketed henna preparations are mixed with different additives to obtain different color shades. The polluted environment in which this plant is cultivated affects also its contents of heavy metals.

The relatively high heavy metal contents found in some henna brands in this present work mainly for $\mathrm{Cd}$, comparing to data from literature, rise serious concerns about possible health problems that daily use of such products can possibly cause, whether through percutaneous absorption or through accidental ingestion. In fact, cadmium is not known to have a physiological function in the human organism, but it is highly toxic even at very low concentrations [60]. An increase level of cadmium has been reported to cause inhibition of DNA mismatches [61] and acute damage to organs such as kidneys, liver, and lungs [60]. Although zinc is not involved in cellular redox cycle and has traditionally been regarded as relatively nontoxic, recent studies increasingly show that free ionic zinc is a potent killer of neurons, glia, and other cells type. Skin contact with zinc powders or concentrated solutions can result in severe corrosive effects including ulceration, blistering, and permanent scarring [62]. Contact dermatitis has been reported in rare instances, following the use of shampoos containing zinc pyrithione but the specific etiological role for zinc was not clear [62]. Zinc has been reported to cause the same signs of illness as does $\mathrm{Pb}$ and can be mistakenly diagnosed as $\mathrm{Pb}$ poisoning [61]. Copper builds up first in the liver and disrupts the liver's ability to detoxify the blood in general, causing fatal health problems. In addition, $\mathrm{Cu}$ is a very stimulating mineral to the nerves and nervous system. Copper toxicity can give rise to many psychological imbalances such as mood swings, depression, anxiety, restlessness, and insomnia [63].

Taking into consideration the relatively high levels of $\mathrm{Pb}$ and $\mathrm{Cd}$ found in the tested products and their toxicity, an immediate mandatory regular testing program must be conducted to check toxic metals in all the kohl and henna products sold in local markets in order to safeguard the consumer health.

\section{Conclusions}

The data presented in this work provides useful information about $\mathrm{Pb}, \mathrm{Cd}, \mathrm{Cu}$, and $\mathrm{Zn}$ contents in kohl and henna, two most commonly used traditional cosmetic products marketed in Tunisia. Twenty-three items were tested representing twelve henna samples and eleven kohl products.

Some of the products were locally manufactured. The rest were imported mainly from eastern countries. Overall, the study revealed that the heavy metal levels mainly in kohl products were far above the recommended limits. Locally manufactured kohl products contained high amount of $\mathrm{Pb}$ and $\mathrm{Cd}$. As for henna samples, considerable amounts of $\mathrm{Cd}$ were found in some local brands highlighting the extent of environmental pollution in the southeast of Tunisia. The high contents of heavy metals in some imported brands may evoke the possibility of spuriousness. Despite the sharp drop in lead poisoning among the human population primarily associated with control of exposure sources such as gasoline, paint, and various consumer products, lead exposure remains present through less well identified sources. Thereby, physicians should raise awareness and encourage people to avoid the use of kohl and henna products especially pregnant women unless there is a certainty that they are lead-free products.

Since there are no proper safety regulations in Tunisia, strict legislations must be established to enforce the acceptable limits of potential contaminants in cosmetics and the good manufacturing practice. Regular inspection of marketed products should be also conducted by the concerned authorities to detect any fraudulent or hazardous product. The sale of any unlabeled or noncompliant product should be also prohibited especially for kohl products due to their major risk especially on the health of young children and pregnant women.

\section{Conflict of Interests}

The authors declare that there is no conflict of interests regarding the publication of this paper.

\section{References}

[1] L. J. Loretz, A. M. Api, L. Babcock et al., "Exposure data for cosmetic products: facial cleanser, hair conditioner, and eye shadow," Food and Chemical Toxicology, vol. 46, no. 5, pp. 15161524, 2008.

[2] G. J. Nohynek, E. Antignac, T. Re, and H. Toutain, "Safety assessment of personal care products/cosmetics and their ingredients," Toxicology and Applied Pharmacology, vol. 243, no. 2, pp. 239-259, 2010.

[3] K. Tomankova, K. Kejlova, S. Binder et al., "In vitro cytotoxicity and phototoxicity study of cosmetics colorants," Toxicology in Vitro, vol. 25, no. 6, pp. 1242-1250, 2011. 
[4] M. G. Volpe, M. Nazzaro, R. Coppola, F. Rapuano, and R. P. Aquino, "Determination and assessments of selected heavy metals in eye shadow cosmetics from China, Italy, and USA," Microchemical Journal, vol. 101, pp. 65-69, 2012.

[5] E.-L. Sainio, R. Jolanki, E. Hakala, and L. Kanerva, "Metals and arsenic in eye shadows," Contact Dermatitis, vol. 42, no. 1, pp. $5-10,2000$.

[6] M. A. Healy and M. Aslam, "Identification of lead in Asian cosmetics-a test for use by health visitors," Public Health, vol. 98, no. 6, pp. 361-366, 1984.

[7] C. Parry and J. Eaton, "Kohl: a lead-hazardous eye makeup from the third world to the first world," Environmental Health Perspectives, vol. 94, pp. 121-123, 1991.

[8] R. V. Sprinkle, "Leaded eye cosmetics: a cultural cause of elevated lead levels in children," The Journal of Family Practice, vol. 40, no. 4, pp. 358-362, 1995.

[9] A. M. Alkhawajah, "Alcohol use in Saudi Arabia, extent of use and possible lead toxicity," Tropical and Geographical Medicine, vol. 44, no. 4, pp. 373-377, 1992.

[10] A. D. Hardy, R. I. Walton, and R. Vaishnav, "Composition of eye cosmetics (kohls) used in Cairo," International Journal of Environmental Health Research, vol. 14, no. 1, pp. 83-91, 2004.

[11] A. D. Hardy, R. Vaishnav, S. S. Z. Al-Kharusi, H. H. Sutherland, and M. A. Worthing, "Composition of eye cosmetics (kohls) used in Oman," Journal of Ethnopharmacology, vol. 60, no. 3, pp. 223-234, 1998.

[12] A. D. Hardy, H. H. Sutherland, and R. Vaishnav, "A study of the composition of some eye cosmetics (kohls) used in the United Arab Emirates," Journal of Ethnopharmacology, vol. 80, no. 2-3, pp. 137-145, 2002.

[13] M. A. Worthing, H. H. Sutherland, and K. Al-Riyami, "New information on the composition of bint al dhahab, a mixed lead monoxide used as a traditional medicine in Oman and the United Arab Emirates," Journal of Tropical Pediatrics, vol. 41, no. 4, pp. 246-247, 1995.

[14] M. A. Healy, P. G. Harrison, M. Aslam, S. S. Davis, and C. G. Wilson, "Lead sulphide and traditional preparation: routes for ingestion, and solubility and reactions in gastric fluid," Journal of Clinical and Hospital Pharmacy, vol. 7, no. 3, pp. 169-173, 1982.

[15] US Food and Drug Administration (FDA), "Automatic detention of eye area cosmetics containing Kohl, Kajal or Surma," Import Alert 53-13, 1996.

[16] US Food and Drug Administration (FDA), Office of Cosmetics and Colors: Eye Cosmetics Safety, 2001, http://www.fda.gov/ cosmetics/productsingredients/products/ucm137250.htm.

[17] M. A. Gondal, Z. S. Seddigi, M. M. Nasr, and B. Gondal, "Spectroscopic detection of health hazardous contaminants in lipstick using laser induced breakdown spectroscopy," Journal of Hazardous Materials, vol. 175, no. 1-3, pp. 726-732, 2010.

[18] N. M. Hepp, W. R. Mindak, and J. Cheng, "Determination of total lead in lipstick: development and validation of a microwave-assisted digestion, inductively coupled plasmamass spectrometric method," Journal of Cosmetic Science, vol. 60, no. 4, pp. 405-414, 2009.

[19] K. D. Besecker, C. B. Rhoades Jr., and B. T. Jones, "A simple closed-vessel nitric acid digestion method for cosmetic samples," Atomic Spectroscopy, vol. 19, no. 2, pp. 48-54, 1998.

[20] M. Saeed, N. Muhammad, and H. Khan, "Assessment of heavy metal content of branded Pakistani herbal products," Tropical Journal of Pharmaceutical Research, vol. 10, no. 4, pp. 499-506, 2011.
[21] I. Al-Saleh, S. Al-Enazi, and N. Shinwari, "Assessment of lead in cosmetics products," Regulatory Toxicology and Pharmacology, vol. 54, no. 2, pp. 105-113, 2009.

[22] International Atomic Energy Agency AIEA, “Training workshop on the analysis of trace metals in biological and sediments samples: laboratory procedurebook," http://www.cnstn.rnrt.tn/ .../IAEA\%20Recommended\%20An.

[23] N. Lekouch, A. Sedki, A. Nejmeddine, and S. Gamon, "Lead and traditional Moroccan pharmacopoeia," The Science of the Total Environment, vol. 280, no. 1-3, pp. 39-43, 2001.

[24] J. G. Ayenimo, A. M. Yusuf, A. S. Adekunle, and O. W. Makinde, "Heavy metal exposure from personal care products," Bulletin of Environmental Contamination and Toxicology, vol. 84, no. 1, pp. $8-14,2010$.

[25] H. Ullah, S. Noreen, Fozia et al., "Comparative study of heavy metals content in cosmetic products of different countries marketed in Khyber Pakhtunkhwa, Pakistan," The Arabian Journal of Chemistry, 2013.

[26] N. Bernth, O. C. Hansen, S. F. Hansen, and E. Pedersen, "Survey of chemical substances in kohl and henna products," Products, Teknologisk Institut, Environment Protecting Agency, Danish Ministry of the Environment, 2005.

[27] R. M. Al-Ashban, M. Aslam, and A. H. Shah, "Kohl (surma): a toxic traditional eye cosmetic study in Saudi Arabia," Public Health, vol. 118, no. 4, pp. 292-298, 2004.

[28] S. A. F. Al-Hazzaa and P. M. Krahn, "Kohl: a hazardous eyeliner," International Ophthalmology, vol. 19, no. 2, pp. 83-88, 1995.

[29] O. Al-Dayel, J. Hefne, and T. Al-Ajyan, "Human exposure to heavy metals from cosmetics," Oriental Journal of Chemistry, vol. 27, no. 1, pp. 1-11, 2011.

[30] I. C. Nnorom, J. C. Igwe, and C. G. Oji-Nnorom, “Trace metal contents of facial (make-up) cosmetics commonly used in Nigeria," African Journal of Biotechnology, vol. 4, no. 10, pp. 11331138, 2005.

[31] I. A. AI-Saleh and L. Coate, "Lead exposure in Saudi Arabia from the use of traditional cosmetics and medical remedies," Environmental Geochemistry and Health, vol. 17, no. 1, pp. 2931, 1995.

[32] K. N. Jallad and C. Espada-Jallad, "Lead exposure from the use of Lawsonia inermis (Henna) in temporary paint-on-tattooing and hair dying," Science of the Total Environment, vol. 397, no. $1-3$, pp. 244-250, 2008

[33] S. S. Al-Wakeel, "Microbial and heavy metals contamination of herbal medicines," Research Journal of Microbiology, vol. 3, no. 12, pp. 683-691, 2008.

[34] F. R. Gallo, G. Multari, G. Palazzino et al., "Henna through the centuries: a quick HPTLC analysis proposal to check henna identity," Brazilian Journal of Pharmacognosy, vol. 24, no. 2, pp. 133-140, 2014.

[35] J. F. Corbett, "Hair coloring," Clinics in Dermatology, vol. 6, no. 3, pp. 93-101, 1988.

[36] I.-J. Kang and M.-H. Lee, "Quantification of paraphenylenediamine and heavy metals in henna dye," Contact Dermatitis, vol. 55, no. 1, pp. 26-29, 2006.

[37] Health Canada, "Consumer product safety: draft guidance on heavy metal impurities in cosmetics," 2011, http://www.hc-sc.gc .ca/cps-spc/pubs/indust/heavy_metals-metaux_lourds/index-eng .php.

[38] Bkg. 489: Bekendtgørelse om kosmetiske produkter, Bekendtgørelse nr. 489 af 12/06/2003, The Danish implementation of Council Directive 76/768/EEC, Miljøministeriet, Statutory Order 
on Cosmetic Products, Statutory Order of 12.06.2003, Danish Ministry of the Environment (Danish).

[39] Federal Health Office of Germany, "Mitteilung des bundesgesundheitsamtes: Technischvermeidbare gehalte an schwermetallen in Kosmetischen Erzeugnissen," Bundesgesundheitsblatt, vol. 28 , no. 7, p. 216, 1985.

[40] The Cosmetic-Toiletry and Fragrance Association (CTFA), "Comments of the Cosmetic, Toiletry and Fragrance Association regarding the scientific and legal issues associated with nanotechnology in personal care products," Report, The Cosmetic, Toiletry and Fragrance Association (CTFA), 2006.

[41] The Scientific Committee on Cosmetic Products and Non-Food Products Intended for Consumers (SCCNFP), "Opinion Concerning Zinc Oxide," Scientific Committee on Cosmetic Products and Non-Food Products Intended for Consumers (SCCNFP) after the 24th Plenary Meeting of June 2003, http://ec.europa.eu/ health/ph_risk/committees/sccp/documents/out222_en.pdf.

[42] Japan Ministry of Health-Labour and Welfare and Pharmaceutical and Food Safety Bureau, Standards for Cosmetics Notification no. 331, Japan Ministry of Health, Labour and Welfare, Tokyo, Japan, 2000.

[43] M. N. V. Prasad and A. K. Shanker, "Mode of action and toxicity of trace elements," Public Health Reports, vol. 38, no. 21, pp. 1882-1912, 2008.

[44] I. Al-Saleh, M. Nester, E. Devol, N. Shinwari, and S. Al-Shahria, "Determinants of blood lead levels in Saudi Arabian schoolgirls," International Journal of Occupational and Environmental Health, vol. 5, no. 2, pp. 107-114, 1999.

[45] A. Nir, A. Tamir, N. Zelnik, and T. C. Iancu, "Is eye cosmetics a source of lead poisoning?" Israel Journal of Medical Sciences, vol. 28, no. 7, pp. 417-421, 1992.

[46] M. H. Rahbar, F. White, M. Agboatwalla, S. Hozhabri, and S. Luby, "Factors associated with elevated blood lead concentrations in children in Karachi, Pakistan," Bulletin of the World Health Organization, vol. 80, no. 10, pp. 769-775, 2002.

[47] A. Shaltout, S. A. Yaish, and N. Fernando, "Lead encephalopathy in infants in Kuwait. A study of 20 infants with particular reference to clinical presentation and source of lead poisoning," Annals of Tropical Paediatrics, vol. 1, no. 4, pp. 209-215, 1981.

[48] R. Plante, J. L. Benedetti, G. Carrier et al., Nosologic Definition of a Notifiable Disease or a Poisoning and a Significant Exposure: Lead, Institut National de Santé Publique de Québec, 1998.

[49] M. A. Warley, P. Blackledge, and P. O'Gorman, "Lead poisoning from eye cosmetic," British Medical Journal, vol. 1, no. 584, p. 117, 1968.

[50] V. K. Sharma, "Tuberculostatic activity of henna (Lawsonia inermis Linn.)," Tubercle, vol. 74, no. 4, pp. 293-295, 1990.

[51] B. H. Ali, A. K. Bashir, and M. O. M. Tanira, "Anti-inflammatory, antipyretic, and analgesic effects of Lawsonia inermis L. (henna) in rats," Pharmacology, vol. 51, no. 6, pp. 356-363, 1995.

[52] H. S. Muhammad and S. Muhammad, "The use of Lawsonia inermis Linn. (henna) in the management of burn wound infections," African Journal of Biotechnology, vol. 4, no. 9, pp. 934-937, 2005.

[53] Y. Bousliman, R. Eljaoudi, M. Ait Elcadi, A. Laatiris, A. Bouklouze, and Y. Cherrah, "Toxicology of paraphenylenediamine," Toxicology, vol. 18, no. 183, pp. 632-636, 2011.

[54] M. Polat, M. Dikilitas, P. Öztaş, and N. Alli, "Allergic contact dermatitis to pure Henna," Dermatology Online Journal, vol. 15, no. 1, article 15, 2009.
[55] C. J. Le Coz, C. Lefebvre, F. Keller, and E. Grosshans, "Allergic contact dermatitis caused by skin painting (pseudotattooing) with black henna, a mixture of henna and p-phenylenediamine and its derivatives," Archives of Dermatology, vol. 136, no. 12, pp. 1515-1517, 2000.

[56] P. Raupp, J. A. Hassan, M. Varughese, and B. Kristiansson, "Henna causes life threatening haemolysis in glucose-6phosphate dehydrogenase deficiency," Archives of Disease in Childhood, vol. 85, no. 5, pp. 411-412, 2001.

[57] A. N. Kök, V. Ertekin, Y. Bilge, and A. F. Işik, "An unusual cause of suicide: henna (Lawsonia inermis Linn.)," Journal of Emergency Medicine, vol. 29, no. 3, pp. 343-344, 2005.

[58] O. Uygur-Bayramicli, R. Dabak, and M. Sargin, "Acute chemical colitis resulting from oral intake of henna," Journal of Clinical Gastroenterology, vol. 39, no. 10, pp. 920-921, 2005.

[59] D. Amira, I. Gana, A. Nouioui et al., "p-Phenylenediamine poisoning in Tunisia: a case report," Arab Journal of Forensic Sciences and Forensic Medicine, vol. 1, no. 1, pp. 138-142, 2015.

[60] J. B. B. Da Silva, D. L. G. Borges, M. A. M. S. Da Veiga, A. J. Curtius, and B. Welz, "Determination of cadmium in biological samples solubilized with tetramethylammonium hydroxide by electrothermal atomic absorption spectrometry, using ruthenium as permanent modifier," Talanta, vol. 60 , no. 5, pp. 977982, 2003.

[61] O. C. Theresa, O. C. Onebunne, W. A. Dorcas, and I. A. Ogunwande, "Potentially toxic metals exposure from body creams sold in Lagos, Nigeria," Researcher, vol. 3, no. 1, pp. 3037, 2011.

[62] G. J. Fosmire, “Zinc toxicity," The American Journal of Clinical Nutrition, vol. 51, no. 2, pp. 225-227, 1990.

[63] K. R. Nolan, "Copper toxicity syndrome," Journal of Orthomolecular Psychiatry, vol. 12, no. 4, pp. 270-282, 1983. 

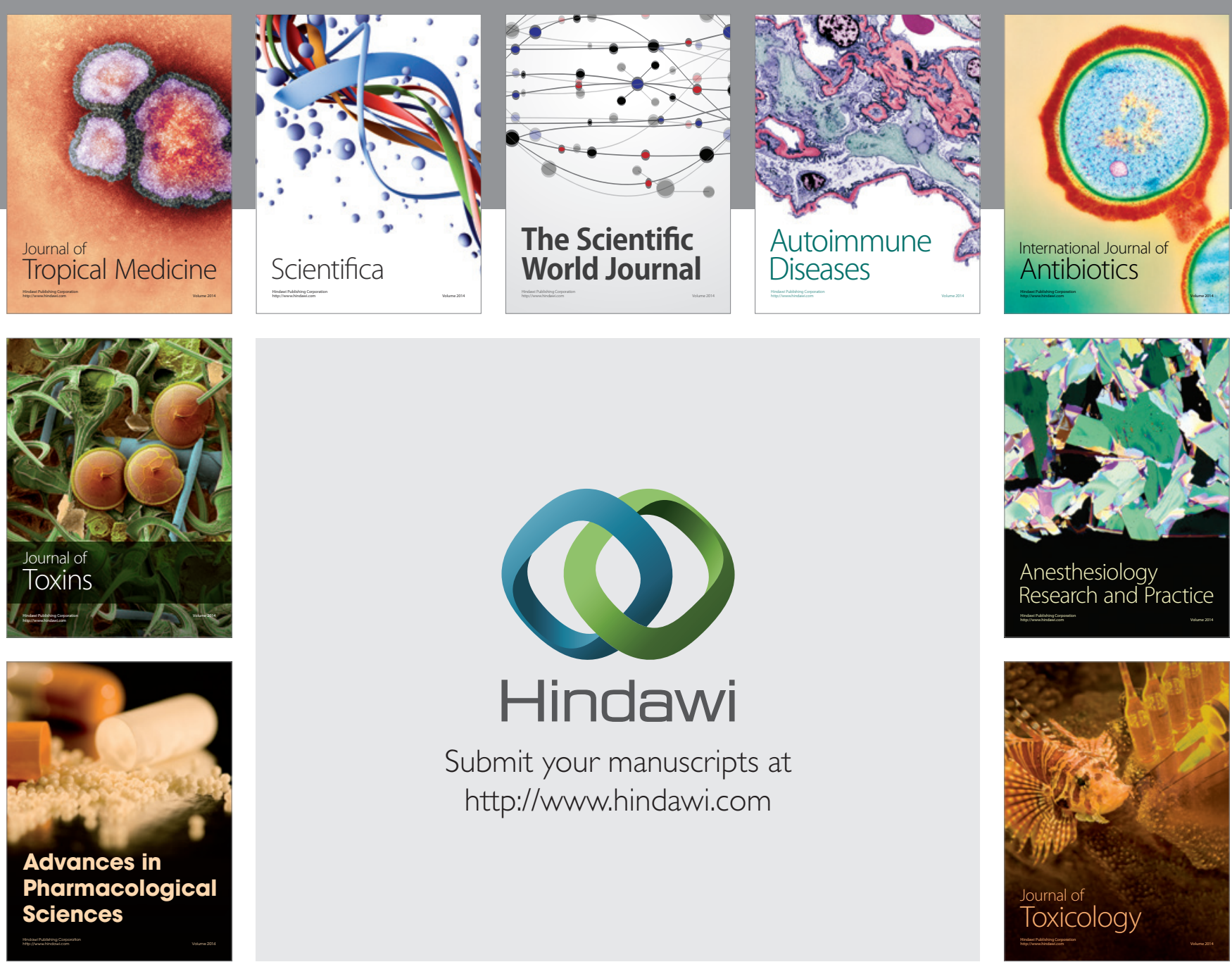

\section{Hindawi}

Submit your manuscripts at

http://www.hindawi.com
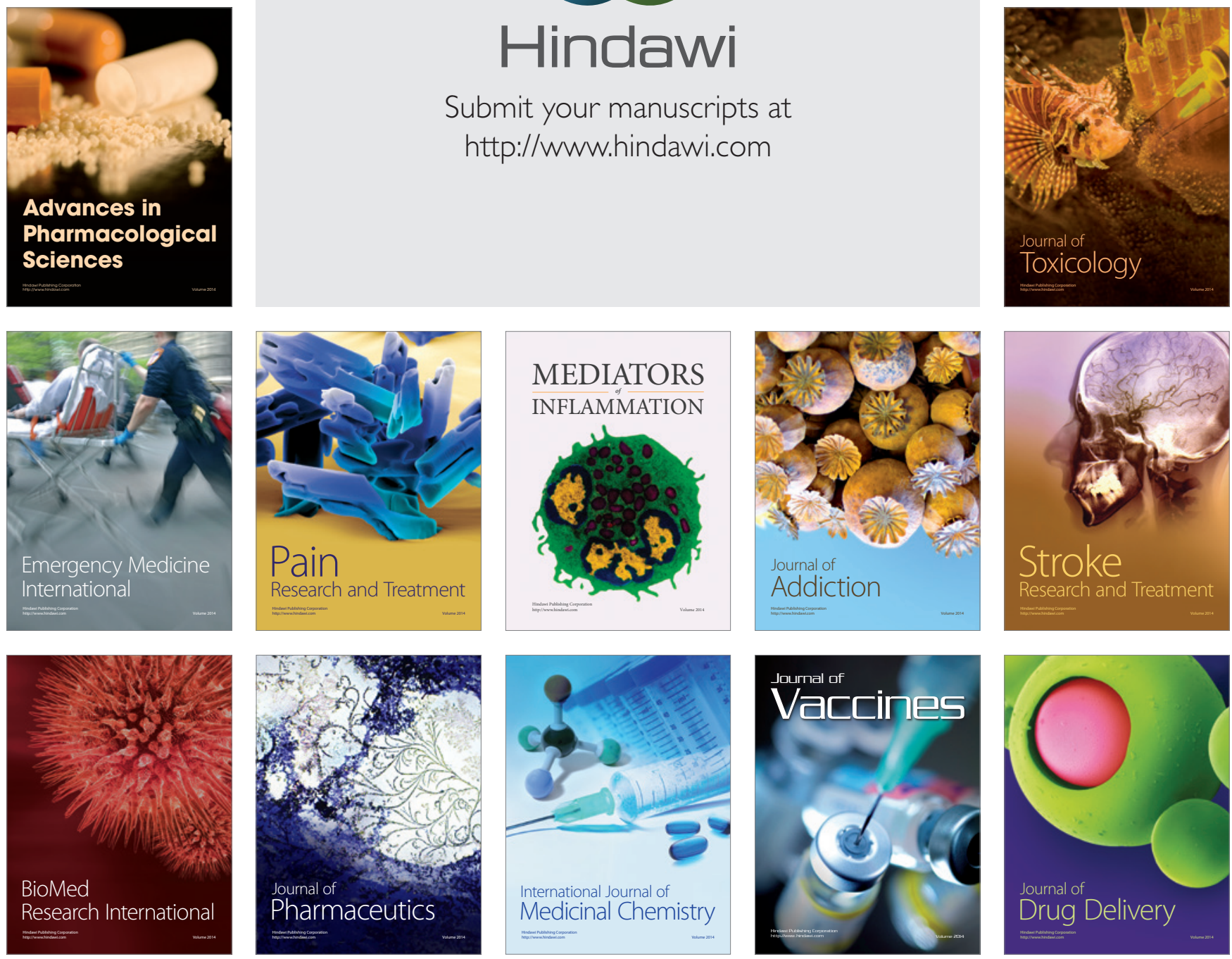